Research article

\title{
Methylation and silencing of the retinoic acid receptor- $\beta 2$ gene in cervical cancer
}

\author{
Tatyana Ivanova ${ }^{1}$, Anatolii Petrenko ${ }^{1}$, Tatyana Gritsko ${ }^{1}$, \\ Svetlana Vinokourova ${ }^{2}$, Ernest Eshilev1, Vera Kobzeva1, Fjodor Kisseljov ${ }^{1}$ and \\ Natalia Kisseljova*1
}

Address: ${ }^{1}$ Institute of Carcinogenesis, Cancer Research Center, Kashirskoye shosse 24, Moscow 115478, Russia and ${ }^{2}$ Division of Molecular Pathology, Department of Pathology, University of Heidelberg, In Neuenheimer Feld 110, 69120 Heidelberg, Germany

E-mail: Tatyana Ivanova - tan_ivanova@mail.ru; Anatolii Petrenko - f_rufa@aport2000.ru; Tatyana Gritsko - gritsko_tatiana@hotmail.com; Svetlana Vinokourova - Vinokourova@mail.ru; Ernest Eshilev - erneste@mail.ru; Vera Kobzeva - vkobzeva@mail.ru;

Fjodor Kisseljov - f.kis@crc.umos.ru; Natalia Kisseljova* - natalia_kis@crc.umos.ru

${ }^{*}$ Corresponding author †Equal contributors

Published: 21 March 2002

BMC Cancer 2002, 2:4

This article is available from: http://www.biomedcentral.com/I47/-2407/2/4

(C) 2002 Ivanova et al; licensee BioMed Central Ltd. Verbatim copying and redistribution of this article are permitted in any medium for any purpose, provided this notice is preserved along with the article's original URL.
Received: 21 December 200I

Accepted: 21 March 2002

\begin{abstract}
Background: Expression of the retinoic acid receptor $\beta 2$ (RAR- $\beta 2$ ), a putative tumor suppressor gene, is reduced in various human cancers, including squamous cell carcinomas (SCC) of the uterine cervix. The mechanism of the inhibition of RAR- $\beta 2$ expression remains obscure. We examined whether methylation of RAR- $\beta 2$ gene could be responsible for this silencing in cervical SCC.
\end{abstract}

Methods: Expression of RAR- $\beta 2$ mRNA and methylation status of the 5 ' region of RAR- $\beta 2$ gene were examined in 20 matched specimens from patients with cervical SCC and in three cervical cancer cell lines by Northern blot analysis and methylation-specific PCR (MSP) assay or Southern blot analysis respectively.

Results: In 8 out 20 cervical SCC (40\%) the levels of RAR- $\beta 2$ mRNA were decreased or undetectable in comparison with non-neoplastic cervix tissues. All 8 tumors with reduced levels of RAR- $\beta 2$ mRNA expression showed methylation of the promoter and the first exon expressed in the RAR- $\beta 2$ transcript. The RAR- $\beta 2$ gene from non-neoplastic cervical tissues was mostly unmethylated and expressed, but methylated alleles of the gene were found in three samples of the morphologically normal tissues adjacent to the tumors. Three cervical cancer cell lines with extremely low level of RAR- $\beta 2$ mRNA expression, SiHA, HeLA and CaSki, also showed methylation of this region of the RAR- $\beta 2$ gene.

Conclusions: These findings suggest that methylation of the $5^{\prime}$ region of RAR- $\beta 2$ gene may contribute to gene silencing and that methylation of this region may be an important and early event in cervical carcinogenesis. These findings may be useful to make retinoids more effective as preventive and therapeutic agents in combination with inhibitors of DNA methylation. 


\section{Background}

Vitamin A and its biologically active metabolites, the retinoids, are essential for the maintenance of normal epithelial differentiation [1]. Retinoid-deficient epithelial tissues acquire a premalignant phenotype, which is characterized by enhanced mitotic activity and loss of differentiation [2]. Retinoids have been used as chemopreventive and chemotherapeutic agents for various human cancers [3].

The antiproliferative and differentiative effects of retinoids are mediated through two classes of nuclear receptors, the RARs and RXRs. Both classes consist of three members, $\alpha, \beta$ and $\gamma[4]$. All these receptors are ligand-activated transcription factors. They activate transcription by binding to retinoic acid response elements (RAREs) located in the promoter regions of the target genes. One of the targets of retinoid receptors is the RAR- $\beta$ gene itself. The RAR- $\beta$ gene encodes for four transcripts and is expressed in normal epithelial tissue, where its expression is up-regulated by treatment with retinoic acid (RA) [5,6]. Recent studies have demonstrated that in many malignant cell lines derived from various carcinomas the level of RAR- $\beta 2$ mRNA (one of four transcripts of this gene) is decreased or undetectable [7-9]. A decrease of RAR- $\beta 2$ mRNA level (compared to normal tissues) was also observed in carcinomas of cervix [10], and in carcinomas of head and neck [11]. These findings indicate that the specific loss of RAR$\beta 2$ mRNA expression may be an important event in tumorogenesis. This hypothesis has been supported by an observation that RAR- $\beta 2$ can function as a tumor suppressor gene in two different carcinoma cell lines $[12,13]$. Thus, a defect in RAR- $\beta 2$ expression may be one of the events that lead the tumor cells to the escape from growth regulation.

The etiology of cancer of the uterine cervix has been associated with several types of human papillomaviruses ("high-risk" HPVs) [14]. In addition to growth regulation, the product of RAR- $\beta$ gene can inhibit transcription of the viral oncogenes (E6 and E7 genes) in high-risk HPV-immortalized cells [15]. The decrease of the expression of negative regulator of viral oncogene may be an additional important step on the way towards malignant progression of HPV-positive cells in this case.

It has been shown that the retinoic acid can induce an increase of RAR- $\beta 2$ expression in carcinoma cells [16] and in lesions of the oropharynx [17]. RA treatment has inhibited transformation of human keratinocytes by HPV-16 [18] and has enhanced regression of cervical moderate dysplasia [19]. Beneficial effects of RA treatment of advanced cervical squamous cell carcinomas (in combination with interferon $\alpha$ ) have been demonstrated in clinical trials [20]. On the other hand, the existence of retinoic acid-insensitive cancer cell lines, including cervical carcinoma cell lines, and the lack of clinical effects of retinoids treatments in some cases are well established [21,22].

The mechanism of the down-regulation and the loss of RA-inducible expression of RAR- $\beta 2$ in cervical carcinomas and cell lines derived from them is not well understood yet. Recent findings have shown that hypermethylation of the promoter region is implicated in the transcriptional silencing of many tumor suppressor genes and several other genes functionally important in neoplastic process [23]. The promoter regions of many genes, including RAR- $\beta 2$, contain $\mathrm{CpG}$ islands, that are protected from methylation in normal cells [24]. Aberrant methylation of CpG islands in tumors serves as an alternative pathway (in addition to intragenic mutations and loss of chromosomal loci) for complete inactivation of tumor suppressor genes. Hypermethylation of normally unmethylated $\mathrm{CpG}$ islands in the 5 ' region of the RAR- $\beta 2$ gene has been observed in breast and colon cancer cell lines, that do not express RARB2 mRNA [25-29].

In this study we examined whether the methylation could be responsible for the deficit of RAR- $\beta 2$ gene expression in cervical squamous cell carcinomas.

\section{Materials and Methods Tissue specimens}

Specimens of cervical tumor were collected in the Department of Radiosurgery of Russian Cancer Research Center: 20 specimens of invasive squamous cell carcinoma with low and moderate levels of differentiation and I, II and III FIGO stages and 20 specimens of morphologically normal tissues of cervix from the same patients. All tumors were HPV16- or HPV18-positive by PCR analysis.

\section{Cell lines}

The human cervical carcinoma cell HeLa, SiHa and CaSki (American Type Culture Collection, Rockville, MD) were maintained in DMEM, supplemented with 10\% FCS and $2 \mathrm{mM}$ glutamine.

\section{DNA and RNA preparations}

DNA and RNA were isolated from frozen tissues homogenized in the $4.5 \mathrm{M}$ solution of guanidine thiocyanate by centrifugation through cesium chloride cushion, as described previously [30].

\section{Northern blot analysis}

$10 \mu \mathrm{g}$ of total RNA was fractionated in $0.8 \%$ formaldehyde agarose gel and transferred to "Hybond $\mathrm{C}$ extra" nitrocellulose membrane (Amersham, UK) according to Sambrook et al. [31]. The membranes were hybridized with ${ }^{32}$ P-labelled $650 \mathrm{bp}$ and $610 \mathrm{bp}$ EcoRI fragments of RAR- $\beta 2$-specific DNA. In order to control the relative 
amounts of RNA the membranes were hybridized to glyceraldehyde-3-phosphate dehydrogenase (GAPDH) DNA probe. Hybridization was performed in $5 \times \mathrm{SSC}$ at $42^{\circ} \mathrm{C}$ in the presence of $50 \%$ formamide. The membranes were washed in $2 \times \mathrm{SSC}, 1 \% \mathrm{SDS}$ at $65^{\circ} \mathrm{C}$ and were exposed to $\mathrm{X}$-ray film at $-70^{\circ} \mathrm{C}$.

\section{Southern blot analysis}

$10 \mu \mathrm{g}$ of DNA was digested overnight with MspI or HpaII restriction enzymes (10 units/ $\mu \mathrm{g}$ of DNA, SibEnzyme, Novosibirsk, Russia). The restriction fragments were separated in $1 \%$ agarose gel, transferred to nylon membrane (Zeta-Probe, Bio-Rad, USA) and hybridized with 32P-labelled PCR DNA probe. PCR DNA probe was prepared by PCR amplification of a 680 bp fragment of RAR- $\beta 2$ promoter and exon_3 with primers: forward, 5'-ATT TGA AGG TTA GCA GCC CG and reverse 5'-CAT TCG GTT TGG GTC AAT CC, in the following conditions: $94^{\circ} \mathrm{C}$ for $3 \mathrm{~min}$, 30 amplification cycles $\left(94^{\circ} \mathrm{C}, 30 \mathrm{sec} ; 56^{\circ} \mathrm{C}, 30 \mathrm{sec} ; 72^{\circ} \mathrm{C}\right.$, $1 \mathrm{~min}$ ) and $72^{\circ} \mathrm{C}, 5 \mathrm{~min}$. Hybridization and washing conditions were as described for RNA.

\section{Methylation-specific PCR (MSP) assay [32]}

Bisulfite conversion reaction was carried out according to S.J. clark et al. [33] with minor modifications. DNA (2 $\mu \mathrm{g})$ was digested with RsaI restriction enzyme (SibEnzyme, Novosibirsk, Russia), denaturated by addition of $\mathrm{NaOH}$ to a final concentration $0.3 \mathrm{M}$, incubated for 15 minutes at $37^{\circ} \mathrm{C}$ and 3 minutes at $95^{\circ} \mathrm{C}$, followed by cooling on ice. Sodium bisulfite and hydroquinone were added to the denatured DNA to final concentration $3.6 \mathrm{M}$ and 0.5 $\mathrm{mM}$, respectively. The sample was overlaid with mineral oil and incubated at $65^{\circ} \mathrm{C}$ for 16 hours. The DNA was purified using QIAEX II kit (Qiagen), desulfonated by addition of $\mathrm{NaOH}$ to a final concentration $0.3 \mathrm{M}$ and incubation at $37^{\circ}$ for $15 \mathrm{~min}$, neutralized with $3 \mathrm{M}$ ammonium acetate ( $\mathrm{pH} 7.0$ ), precipitated with 3 volumes of ethanol, resuspended in $\mathrm{H}_{2} \mathrm{O}$ and stored at $-20^{\circ} \mathrm{C}$.

Primers that were specific for the upper strand of bisulfitemodified DNA and did not contain CpG dinucleotides in the original sequences were used in the first round of PCR: forward 5'-AAG TGA GTT GTT TAG AGG TAG GAG GG and reverse 5'-CCT ATA ATT AAT CCA AAT AAT CAT TTA CC [28]. 5-20 ng of DNA was amplified with these primers in the following conditions: $94^{\circ} \mathrm{C}, 5 \mathrm{~min} ; 35$ amplification cycles $\left(94^{\circ} \mathrm{C}, 15 \mathrm{sec} ; 53^{\circ} \mathrm{C}, 15 \mathrm{sec}\right.$ and $\left.72^{\circ} \mathrm{C}, 30 \mathrm{sec}\right)$ and $72^{\circ} \mathrm{C}, 5 \mathrm{~min}$. The obtained DNA fragments were amplified in the second round of PCR with two set of primers specific for the upper strand of bisulfite-modified DNA, which contains CpG dinucleotides: 1) forward 5'-TTG AGA ATG TGA GTG ATT TGA and reverse 5'-AAC CAA TCC AAC CAA AAC AA for the unmethylated sequence $(\mathrm{U}), 2$ ) forward 5'-TCG AGA ACG CGA GCG ATT CG and reverse 5'-GAC CAA TCC AAC CGA AAC GA for the meth- ylated sequence $(\mathrm{M})$. The PCR was performed under the following conditions: $94^{\circ} \mathrm{C}, 2 \mathrm{~min} ; 40$ cycles $\left(94^{\circ} \mathrm{C}, 30 \mathrm{~s}\right.$; $50^{\circ} \mathrm{C}, 30 \mathrm{~s}$ and $72{ }^{\circ} \mathrm{C}, 30 \mathrm{~s}$ for U-primers) and 35 cycles $\left(94^{\circ} \mathrm{C}, 30 \mathrm{~s} ; 58^{\circ} \mathrm{C}, 30 \mathrm{~s}\right.$ and $72^{\circ} \mathrm{C}, 30 \mathrm{~s}$ for M-primers) and $72^{\circ} \mathrm{C}, 5 \mathrm{~min}$. The PCR products were fractionated in the $3 \%$ agarose gel and photographed.

\section{Results \\ RAR- $\beta 2$ mRNA expression}

The level of the expression of RAR- $\beta 2$ mRNA was evaluated in 20 samples of invasive squamous cell carcinomas of uterine cervix at low and moderate levels of differentiation and in the morphologically normal tumor-adjacent tissues of cervix in order to select a group of tumors with deficient expression of RAR- $\beta 2$ (Figure $1 \mathrm{~B}$, Table 1 ). The level of RAR- $\beta 2$ mRNA expression was significantly decreased in 8 out of 20 tumors constituting $5-48 \%$ of the expression level of the corresponding morphologically normal tissue. An extremely low (undetectable) level of mRNA expression was observed in one tumor, as well as in the adjacent morphologically normal tissue (Fig. 1B, lanes 5,6; Table 1, case 7). Thus, in $40 \%$ of cervical SCC the expression of the RAR- $\beta 2$ mRNA was significantly decreased. An extremely low level of mRNA expression, wich was observed earlier in three cell lines HeLA, SiHa and CaSki [22], was confirmed in our experiment (data are not presented).

\section{Methylation status of the $R A R-\beta 25^{\prime}$ region}

The methylation status of the 5 ' region of the gene was studied in order to determine if this DNA modification, which inhibits transcription, contributes to the inhibition of the expression of the RAR- $\beta 2$ mRNA. The study was carried out by two independent methods: by Southern blot analysis and by methylation-specific PCR assay. The localization of the recognition sites for the methylation-sensitive restriction enzyme Hpa II within the promoter region and the first transcribed exon of the RAR- $\beta 2$ transcript (exon 3 ) is presented on the fig. 1A. The sizes of the fragments, which are produced when the restriction sites are methylated and can not be digested by Hpa II, are indicated in the lower part of the fig. 1A. The control digestion of DNA by Msp I (cuts at the identical to Hpa II site even if the cytosine residue is methylated) produced only one major band $1.1 \mathrm{kbp}$ (Fig. 1C, lanes 1, 3, 5, 7, 9, 11, 13, $15)$. The absence of the $1.1 \mathrm{kbp}$ band, as well as that of 1.15 - $1.6 \mathrm{kbp}$, after the digestion of the DNA by Hpa II indicates that the $\mathrm{H} 1-\mathrm{H} 5$ sites are methylated (Fig. 1C, lanes $8,10,12,14,16)$. The presence of $1.1 \mathrm{kbp}$ band and the absence of any additional bands indicates that these sites are unmethylated (Fig 1C, lanes 2, 4, 6). As demonstrated by Southern blot analysis, all analyzed sites were methylated in 6 out of 8 carcinomas with the deficit of the RAR- $\beta 2$ mRNA (Table 1). It was impossible to perform this analysis in two carcinomas due to lack of adequate 

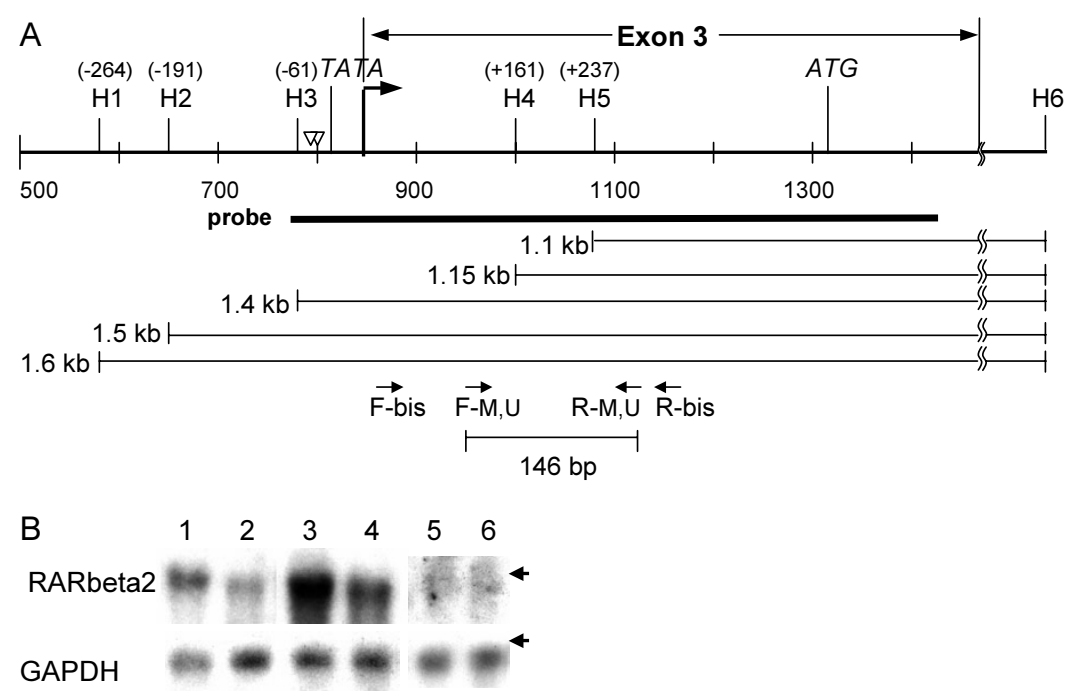

C

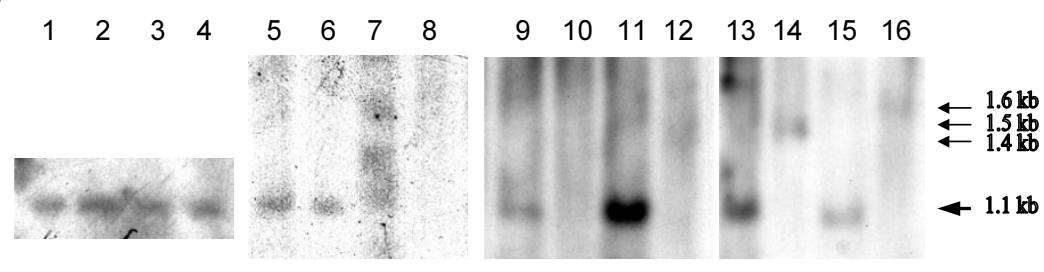

D

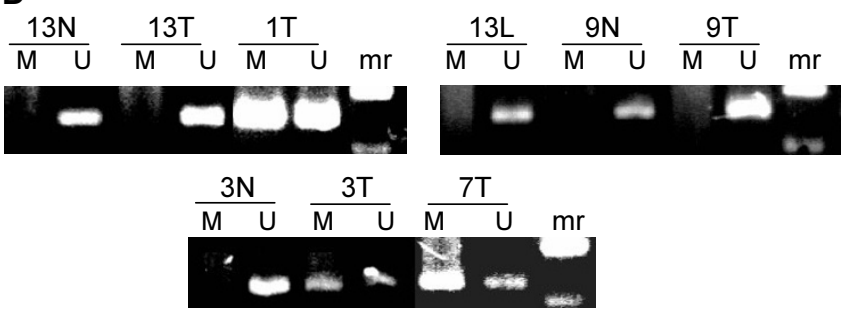

Figure I

A. Restriction map of promoter-exon region of RAR 32 gene for methylation-sensitive Hpa II enzyme. The bolt line shows the 680 bp DNA probe generated by PCR of the promoter and exon 3. The expected fragment sizes which are recognized by this probe are shown in the bottom part of the map. The transcription start site is indcated by broken arrow. The positions of the primers for MSP assay are indicated by arrows. The I46 bp fragment is the region analyzed for CpG methylation by MSP assay. The triangles show the positions of two RAREs within the promoter region. $\mathrm{H}-\mathrm{Hpall}$ sites, the positions of the Hpa II sites in relation to the trascription start site are indicated by fugures in bp. B. Northern blot analysis of total RNA isolated from cervical carcinomas (T) and adjacent cervical normal tissues (N). The blots were hybridized with ${ }^{32} \mathrm{P}$ labeled DNA probes for RAR 32 and GAPDH. Lanes I, $2-4 \mathrm{~N}, 4 \mathrm{~T}$, lanes 3, 4-5N, 5T, lanes 5,6-7N, 7T respectively. Case numbers correspond to that indicated in table I. The arrows show the positions of 28S and I8S RNA. C. Southern blot analysis of DNA isolated from cervical carcinomas (T) and adjacent cervical normal tissues (N). The blots were hybridized with 680 bp $32 \mathrm{P}$ labeled DNA probe for RAR $\beta 2$. The bold arrow shows the positions of a minimal I.I kbp fragment, recognized by this probe. Lanes I, 3, 5, 7, 9, II, I3, I5 - DNA digested by Mspl; lanes 2, 4, 6, 8, I0, I2, I4, I6 - DNA digested by Hpall; lanes I, 2 - 9N; lanes 3, 4-9T; lanes 5,6 - 4N; lanes 7, 8-4T; lanes 9, I0 - 7N; lanes II, I2 - 7T; lanes I3, I4 - SiHa; lanes 15, 16 - HeLa. Case numbers correspond to that indicated in table I. D. MSP assay of DNA isolated from cervical carcinomas (T), adjacent cervical normal tissues (N) and leucocytes (L). All DNA samples were treated with sodium bisulfite before amplification of a 146 bp fragment with methylation-specific primers (M) and unmethylation-specific primers (U). Sample numbers on the top of the gel correspond to that indicated in table I; $\mathrm{mr}-$ molecular weight marker. 
Table I: Methylation Status of RAR $\beta 25^{\prime}$ region in cervical SCC and cervical cancer cell lines

\begin{tabular}{|c|c|c|c|}
\hline $\begin{array}{l}\text { Case number or } \\
\text { type of cells }\end{array}$ & $\begin{array}{c}\text { RNA expression } \\
\%^{*}\end{array}$ & $\begin{array}{c}\text { Southern blot } \\
\text { analysis }\end{array}$ & MSP assay \\
\hline 1 & 5 & nd & $M$ \\
\hline 2 & 19 & $M$ & Nd \\
\hline 3 & 48 & $M$ & $M$ \\
\hline 4 & 22 & $M$ & $M$ \\
\hline 5 & 26,5 & $M$ & $M$ \\
\hline 6 & 18 & $M$ & $M$ \\
\hline 7 & $* *$ & $M$ & $M$ \\
\hline 8 & 19 & nd & $M$ \\
\hline $9-20$ & $95-103$ & $U$ & $U$ \\
\hline HeLa & ** & $M$ & $M$ \\
\hline $\mathrm{SiHa}$ & $* *$ & $M$ & $M$ \\
\hline CaSki & $* *$ & nd & $M$ \\
\hline
\end{tabular}

* The expression levels of RAR $\beta 2$ mRNA in carcinomas relative to morphologically normal tissues (\%), determinations by Northern blot analysis; the RAR $\beta 2$ mRNA levels have been normalized to GAPDH.

** Expression of RAR $\beta 2$ mRNA was extremely low in tumor and

morphologically normal tissue or cell lines. nd - not done

amounts of DNA. Methylation of this region was found in the morphologically normal tissue in the case 7 (Fig. 1C, lane 10). This result correlated with the absence the mRNA expression in this samples (Fig. 1B, lane 5). Two cervical cancer cell lines, showed methylation of this region also (Fig 1C, lanes 14, 16).

The same samples were subjected to the MSP assay. The MSP assay allows detection of methylated, as well as of unmethylated alleles after the modification of DNA by sodium bisulfite. The presence of nonmalignant cells (fibroblasts, blood cells and some normal epithelial cells) in tumor specimens does not interfere with the ability to detect methylation. The sensitivity of this assay to detect methylated alleles in the background of unmethylated alleles is $>10^{-4}$ [32]. The result of a typical experiment with a set of primers, that amplify a $146 \mathrm{bp}$ product in the region of $\mathrm{H} 4$ and $\mathrm{H} 5$ sites of $\mathrm{Hpa}$ II (5' untranslated region, $5^{\prime}$ UTR), is presented on the fig. 1D. The presence of an amplification product obtained in the reaction with methyl-specific primers $(\mathrm{M})$ indicates for the methylation (Fig. 1D, samples IT, 3T, 7T). The absence of this product indicates for the absence of the methylated alleles (Fig. 1D, samples 13T, 9T, 13L and all $\mathrm{N}$ samples). Amplification with primers, which are specific for the unmethylated sequence $(U)$, demonstrated that this region is mostly demethylated. It should be noted, that in all tumor samples, that bear the methylated alleles, we detected at least traces of the products of amplification with $U$ primers. Apparently, the nonmalignant cells, that are present in tumor specimens serve as a source of this product. Both primer pairs ( $\mathrm{M}$ and $\mathrm{U}$ ) do not react with DNA, which was not treated with bisulfite (data not shown). Thus, the presence of an amplification product in the reaction with the U primers serves as a control of a correct DNA modification by bisulfite in the case of a negative reaction with the M primers. The results of the MSP assay confirmed the methylated status of DNA in the 5' UTR region of RAR- $\beta 2$ gene in tumors with decreased level of mRNA expression and in all cervical cancer cell lines examined. (Table 1). In addition to one case, which was detected by Southern blot analysis, two patients were found to produce a poor amplification with the $\mathrm{M}$ primers in morphologically normal tissues (data not shown).

Thus, methylation of $\mathrm{CpG}$ site in the promoter and the $5^{\prime}$ UTR region of RAR- $\beta 2$ gene was detected in all 8 tumor samples with deficient expression of the RAR- $\beta 2$ mRNA and all cervical cancer cell lines. Methylation of this region was not found in the tumors with normal expression levels of the RAR- $\beta 2$ mRNA.

\section{Discussion}

RAR- $\beta 2$ is a putative tumor suppressor. Complete or partial inhibition of the expression of the gene was observed in many tumor cell lines and in primary human tumors $[7-11,22]$. It was demonstrated in this study, that in 8 out of 20 SCC of cervix a deficient expression of the RAR- $\beta 2$ mRNA was observed in comparison to the matched morphologically normal tissue of cervix.

The mechanism of the inhibition of RAR- $\beta 2$ expression remains obscure. It was demonstrated in the tumor cells lines derived from breast and colon carcinomas, that the expression of RAR- $\beta 2$ mRNA is silenced by methylation of the promoter and the first exon, that is expressed in the RAR- $\beta 2$ transcript. Treatment of DNA by demethylating agent 5-aza-2'-deoxycytidine restored the inducibility of the gene by all-trans-retinoic acid (ATRA) in many, but not all tumor cell lines. For breast carcinomas a relationship between methylation status and decreased RAR- $\beta 2$ expression was found only in invasive grade II tumors. In grade III tumors the RAR- $\beta 2$ expression was never observed, regardless the methylation status [28]. In all 8 invasive SCC of cervix and in three cell lines, analyzed in our study, the deficit of the expression of the RAR- $\beta 2$ mRNA was associated with methylation of the promoter and the region of the first exon, including the H3 site close to the RARE (Figure 1A). The methylation of this site plays an important role in the repression of the gene transcription in the breast cancer cells [29]. However, recently 5 cervical cancer cell lines were revealed in that the inhibition of the RAR- $\beta 2$ mRNA expression was not associated with the methylation of the same region of the gene [34]. Apparently, some other events together with methylation of the promoter region are involved in gene inactivation in cer- 
tain cancer cell lines and invasive carcinomas. In particular, overexpression of Nur 77 gene has been found to be associated with a loss of RAR- $\beta 2$ inducibility and RA resistance in lung cancer cells [35].

In our study the methylated alleles of RAR- $\beta 2$ were absent in the majority of morphologically normal tissues of cervix. However, methylated alleles of the gene were found in three samples of the normal tissue, which were adjacent to the tumors with methylated status of RAR- $\beta 2$. It can be suggested, that methylation of the normal tissues of cervix is an early preneoplastic event, that favours the development of malignancy. Our data provide only indirect evidence that methylation and the loss of RAR- $\beta 2$ expression are early steps of cervical carcinogenesis. Recently this suggestion was supported by the study, where the methylated alleles of the gene were found in $11 \%$ and $29 \%$ of low grade and of high grade cervical intraepithelial neoplasias respectively [34]. This authors found the methylation of RAR- $\beta 2$ gene in 5 out of 17 invasive carcinomas also. Taken together these data indicate that methylation of RAR$\beta 2$ gene is frequent and early event during cervical cancerogenesis.

\section{Conclusions}

These findings suggest that methylation of the 5 ' region of RAR- $\beta 2$ gene may contribute to gene silencing and that methylation of this region may be an important and early event in cervical carcinogenesis. Cervical carcinomas may serve as a potential target for the DNA methylation inhibitors due to a close correlation between the deficit of RAR$\beta 2$ mRNA expression and methylation of this gene. These inhibitors in combination with retinoids might be clinically useful in future as chemopreventive and chemotherapeutic agents for patients with cervical dysplasias and carcinomas.

\section{Acknowledgements}

We thank Dr. O.V. Sacharova for providing the clinical information and Dr A.F. Kisseleva for technical assistance. This work was supported by grants 97-04-50140 and 0I-04-49225 from the Russian Foundation of Basic Science.

\section{References}

I. Gudas LJ, Sporn MB, Roberts AB: Cellular biology and biochemistry of the retinoids. In: The retinoids: biology, chemistry and medicine. 1994, 443-5 I6

2. Wolbach SB, Howe PR: Tissue changes following deprivation of fat-soluble A vitamin. J Exp Med 1925, 42:753-777

3. Hong WK, Itri LM: Retinoids and human cancer. In: The retinoids: biology, chemistry and medicine. 1994, 387-442

4. Chambon $P$ : The retinoid signaling pathway: molecular and genetic analyses. Semin Cell Biol 1994, 5:1 I5-125

5. de The $H$, Marchino A, Tiollais P, Dejean A: Differential expression and ligand regulation of the retinoic acid receptor $\alpha$ and $\beta$ genes. EMBO / 1989, 8:429-433

6. de The H, Vivanco Ruiz M, Tiollais P, Stunnenberg H, Dejean A: Identification of retinoic responsive element in the retinoic acid receptor gene. Nature 1990, 343:177-180

7. Nervi C, Vollberg TM, George MD, Zelent A, Chambon P, Jetten AM: Expression of nuclear retinoic acid receptors in normal tra- cheobronchial cells and in lung carcinoma cells. Exp Cell Res 1991, 195:163-170

8. Swisshelm K, Ryan K, Lee X, Tsou HC, Peacocke M, Sager R: Downregulation of retinoic acid receptor $\beta$ in mammary carcinoma cell lines and its up-regulation in senescing normal mammary epithelial cells. Cell Growth Differ 1994, 5:133-141

9. Caliaro MJ, Marmouget C, Guichard S: Response of four ovarian carcinoma cell lines to all-trans retinoic acid: relationship with induction of differentiation and retinoic acid receptor expression. Int J Cancer 1994, 56:743-748

10. Comerci JT, Hallam S, Goldberg GL, Runowcz CD, Fields AL, Wadler $S$, Gallagher RE: Expression of retinoic acid receptor- $\beta 2$ mRNA in normal cervical epithelium and cervical squamous cell carcinoma. Int J Oncology 1997, I I:983-988

II. Xu XC, Ro JY, Lee JS, Shin DM, Hong WK, Lotan R: Differential expression of nuclear retinoid receptors in normal, premalignant and malignant head and neck tissues. Cancer Res 1994, 54:3580-3587

12. Houle B, Rochette-Egly C, Bradley WE: Tumor-suppressive effect of the retinoic acid receptor $\beta$ in human epidermoid lung cancer cells. Proc Nat Acad Sci USA 1993, 90:985-998

13. Sabichi AL, Hendrics DT, Bober MA, Birrer MJ: Retinoic acid receptor $p$ expression and growth inhibition of gynecologic cancer cells by the synthetic retinoid $\mathbf{N}$-(4-hydroxyphenyl) retinamide. J Natl Cancer Inst 1998, 90:597-605

14. Zur Hausen H: Papillomavirus infections - a major cause of human cancers. Biochim Biophys Acta 1996, I 288:F55-F78

15. Bartsch D, Boye B, Baust C, zur Hausen H, Schwarz E: Retinoic acid-mediated repression of human papillomavirus 18 transcription and different ligand regulation of retinoic acid receptor $\beta$ gene in nontumorogenic and tumorogenic HeLa hybrid cells. EMBO J 1992, I I:2283-229 I

16. Baust C, Redpath L, Schwarz E: Different ligand responsiveness of human retinoic acid receptor $p$ gene transcription in tumorogenic and nontumorigenic cervical carcinoma-derived cell lines is mediated through a large retinoic acid response domain. Int J Cancer 1996, 67:409-4I6

17. Hong WK, Lippman SM, Hittelman WN, Lotan R: Retinoid chemoprevention of aerodigestive cancer: from basic research to the clinic. Clinic Cancer Res 1995, I:677-686

18. Khan MA, Jenkins GR, Tolleson WH, Creek KE, Pirisi L: Retinoic acid inhibition of human papillomavirus mediated transformation of human keratinocytes. Cancer Res 1993, 53:905-909

19. Meyskens FL, Surwit E, Moon TE, Childers JM, Davis JR, Dorr RT, Jonson CS, Alberts DS: Enhancement of regression of cervical intraepithelial neoplasia II (moderate dysplasia) with topically applied all-trans retinoic acid: a randomized trial. J Natl Cancer Inst 1994, 86:539-543

20. Lippman SM, Kavanagh J, Parades-Espinoza M, Delljadillo-Madrueno F, Paredes-P Casillas, Hong WK, Massimini G, Holdener EE, Kazakoff $\mathrm{IH}$ : I 3-cis-retinoic acid plus iterferon- $\alpha 2 \mathrm{a}$ in locally advanced squamous cell carcinoma of cervix. J Natl Cancer Inst 1993, 85:499-500

21. Geraddts J, Chen JY, Russell EA, Yankaskas JR, Nieves L, Minna JD: Human cancer cell lines exhibit resistance to retinoic acid treatment. Cell Growth Differ 1993, 4:799-809

22. Geisen C, Denk C, Gremm B, Baust C, Karger A, Bollag W, Schwarz $E$ : High-level expression of the retinoic acid receptor $\beta$ gene in normal cells of the uterine cervix is regulated by the retinoic acid receptor $a$ and is abnormally down-regulated in cervical carcinoma cells. Cancer Res 1997, 57: |460-|467

23. Herman JG: Hypermethylation of tumor suppressor genes in cancer. Semin Cancer Biol 1999, 9:359-367

24. AP Bird: CpG-rich islands and the function of DNA methylation. Nature 1986, 32 I:209-213

25. Cote S, Monparler R: Activation of the retinoic acid receptor $\beta$ gene by 5-aza-2'-deoxycytidine in human DLD-I colon carcinoma cells. Anti-Cancer Drugs 1997, 8:56-6I

26. Cote S, Sinnett D, Monparler RL: Demethylation by 5-aza-2'-deoxycytidine of specific 5-methylcytosine sites in the promoter region of the retinoic acid receptor $\beta$ gene in human colon carcinoma cells. Anti-Cancer Drugs 1998, 9:743-750

27. Bovenzi V, Le NLO, Cote S, Sinnett D, Monparler L, Monparler RL: DNA methylation of retinoic acid receptor $\beta$ in breast cancer and possible therapeutic role of 5-aza-2'-deoxycytidine. Anti-Cancer Drugs 1999, 10:471-476 
28. Widschwendter M, Berger J, Hermann M, Muller HM, Amberger A, Zeschnigk M, Widschwendter A, Abendstein B, Zeimet AG, Daxenbichler G, et al: Methylation and silencing of the retinoic acid receptor- $\beta 2$ gene in breast cancer. J Natl Cancer Inst 2000, 92:826-832

29. Arapshian A, Kuppumbatti YS, Mira-y-Lopez R: Methylation of conserved CpG cites neighboring the beta retinoic acid response element may mediate retinoic acid receptor beta gene silencing in MCF-7 breast cancer cells. Oncogene 2000, 19:4066-4070

30. Samoylova E, Shaikhaiev G, Petrov S, Kisseljova N, Kisseljov F: HPV infection in cervical-cancer cases in Russia. Int J Cancer 1995, 6 1:337-34 I

31. Sambrook J, Fritsh EF, Maniatis T: Molecular Cloning. A Laboratory Manual. Cold Spring Harbor, Cold Spring Harbor Press 1989

32. Herman JG, Graff JR, Myohanen S, Nelkin BD, Baylin SB: Methylation-specific PCR: a novel PCR assay for methylation status of CpG islands. Proc Natl Acad Sci USA 1996, 93:982I-9826

33. Clark SJ, Harrison J, Paul CL, Frommer M: High sensitivity mapping of methylated cytosines. Nucl Acids Res 1994, 22:2990-2997

34. Virmani AK, Muller C, Rathi A, Zoechbauer-Muleller S, Mathis M, Gazdar AF: Aberrant methylation during cervical carcinogenesis. Clin Cancer Res 200I, 7:584-589

35. Wu Q, Li Y, Liu R, Agadir A, Lee MO, Lui Y: Modulation of retinoic acid sensitivity in lung cancer cells through dynamic balance of orphan receptors nur77 and COUP-TF and their heterodimerization. EMBO J 1997, 16:1656-1669

\section{Pre-publication history}

The pre-publication history for this paper can be accessed here:

http://www.biomedcentral.com/1471-2407/2/4/prepub

Publish with BioMed Central and every scientist can read your work free of charge

"BioMedcentral will be the most significant development for disseminating the results of biomedical research in our lifetime."

Paul Nurse, Director-General, Imperial Cancer Research Fund

Publish with BMC and your research papers will be:

- available free of charge to the entire biomedical community

- peer reviewed and published immediately upon acceptance

- cited in PubMed and archived on PubMed Central

- yours - you keep the copyright

Submit your manuscript here:

http://www.biomedcentral.com/manuscript/
BioMedcentral.com editorial@biomedcentral.com 